\title{
CHARACTER EDUCATIONAL VALUES ON “AQUAMAN" MOVIE
}

\author{
Pola Esianita; Wiwin Widyawati \\ Institut Agama Islam Negeri (IAIN) Ponorogo \\ polaesianita@gmail.com
}

Abstract

The purposes of doing this research are to find out the types of character education values found in the Aquaman movie, (ii) recognize the character educations values are found in the Aquaman movie that possibly increase student motivation. In this research, the researcher used library research. The data of this research are character educational values in the conversation among the characters of the "Aquaman" movie. The data source in this research is a movie entitled "Aquaman". The result shows that there are 15 types of character educational value spoken by the characters. They are: honesty, tolerance, dicipline, hardworking, creativity, curiosity, national spirit, patriotism, friendly/communicative, peacemaker, environmental care, responsibility, loaylity, respect, love \& afferction. Then, the most dominant Educational values in this movie is responsible and peacemaker value.

Keywords: Character, Education Values, Kemendiknas, and “Aquaman” Movie.

\section{INTRODUCTION}

Nowadays, watching a movie becomes a general activity. The people have different purposes in watching movie such as for refreshing, spending time, getting information and prespective, learning foreign language and try to understand cultures. Most of people like watching no matter their life condition, whatever their background, whoever they are, sexes and ages. Not only in big cities, but also in small town people are watching movie. Due to advance technology development such as internet and smartphone, people can watch movie anytime and anywhere(Humaira, 2018).

Movie is very effective to persuade people mind because it is covered with an interesting plot, and it is easy watching. Because of its persuasive, a consumptoin of movie is being a basic need, even life style. Movie can influence people easily because it is really close to our life. Movie itself is inspired from a real life but it was added some flavours in order to make it more beautiful for entertaiment purpose. From the movie, viewer will be easily persuaded by the actual content presentation the engages audio visual sense so that messages in the movie will be easy to arrive in viewers mind (Christoper \& Jacob, 2013). 
Because movie are familiar, evocative and non-threatning, grounded in both imagery and emotion, its are useful in teaching the human dimension required for developing as human beings and for building identity in young learners (Sharjeel, 2013). For teachers, the movie experience helps also to confirm and clarify their role to bring new prespectives in teaching especially show character educational values.

The formulation of character is one of the national educaional goals. Article 1 of the 2003 Education Law states that among objectives of national education is to develop the potential of learners to have intellegence, personality, and noble character. Currently character of nation strenghtening of the strategic priorities of national education program, given the states of the nation must be returned to the characterization of national identity (Riyana, 2015). Various ways can be made to build character education, including through watching movie.

According to Uswatun Qoyyimah (2015), there are 18 types of character educational values based on Kementrian Pendidikan Nasional (KEMENDIKNAS), include : religiousity, honesty, tolerance, dicipline, hardworking, creaivity, independent, democracy, curiousity, national spirit, patriotism, highly regard achievement, friendly/communicative, peace maker, good reader, environmental care, sociality, responsibility.

Based on the research by Misbachul Anam Irvani (2015) student of State Islamic Institute (IAIN) of Tulungagung, had conducted a research entiteld "Character Educational Values in "The Ron Clark Story" Movie" that proofs there are many character educational values in "The Ron Clark Story" movie directed by Randa Haines. In his thesis, he analyzed 18 character education stated by "KEMENDIKNAS" formulation. From the 18 character educational values above, he got 13 character educational values in "The Ron Clark Story" that are honesty, tolerance, dicipline, hard working, creativity, democratic, curiousity, love homeland, appreciating achievement, friendly, like to read, sociality, and responsibility. In the other hand, 5 of 18 character educational values were not appeared on this movie. That are religious, independent, national spirit, love peace, and environmental care.

Aquaman is one of movie that also has a lot of character educational values for the audience. This movie direced by James Wan and produced by Warner Bros Pictures. From Aquaman movie, the researcher finds something which interest. Started with born upon the shores of the surface world, Arthur Curry discovers that he is only half human with the other half of his blood being of atlantean descent, thus making him the rightful heir to the throne of the undersea kingdom of Atlantis. However, Arthur learns the Atlantis is being ruled by his malicious half brother Orm, who seeks to unite the seven underwater kingdoms and wage war upon the surface. With aid from nuidis Vulko and the gorgeous Mera, Arthur must discover the full potential of his true destiny and become 
Aquaman in order to save Atlantis and the surface from orm's evil plot (Aquaman, 2018). From this movie, the researcher finds that main character's adventure to be a king show more than one educational values we can learn especially leadership and nationalism values. It makes researcher motivated to find know deeply about character educational values in this movie. In the other side, Aquaman is a one of movie include in box office. It can cloncluded that lot of people recognize this movie.

This study focuses on analysis of character educational values in the "Aquaman" movie. The researcher hopes this study would be able to emphasize the important of character educational values to the reader. Therefore, based on explanation above, the writer is going to conduct a research to investigate the character educational values in "Aquaman" movie under the title "An Analysis of Character Educational Values Based on Formulation of Kemendiknas in the year 2013 Related to "Aquaman" Movie".

\section{METHODS}

In conducting this research, the researcher uses the library research and the approach that is used be the writer is descriptive qualitaive. Kothari (2001) stated that "qualitative approach to research is concerned with subjective assessment of attitudes, opinions and behaviour." there are two data sources for the analysis, the "Aquaman" movie video and screenplay. The primary source of the data is the video and screenplay of "Aquaman" movie. The file of the movie video is downloaded from www.Ganool.com. Secondary source is analyze the character educational values in "Aquaman" movie based on KEMENDIKNAS's formulation. There are 18 types of character educational values taken from KEMENDIKNAS's formulation, includes: religiousity, honesty, tolerance, dicipline, hardworking, creativity, independent, democracy, curiousity, national spirit, patriotism, highly regard achievement, friendly/communicative, peace maker, good reader, environmental care, sociality, and responsibility.

In conducting this research, the researcher uses documentary technique to collect the data by getting the data from reading the movie sceenplay and watching of "Aquaman" movie by James Wan. The researcher uses content analysis in which the the researcher tries to analyze data and to identify every utterance using character educational values based on KEMENDIKNAS's formulation. Then, the researcher describes the data which will answer the two research problem of analsis above.

\section{FINDINGS AND DISCUSSION}

Aquaman movie was directed by James Wan and written by Geoff Johns, James Wan and Wll Beall. The movie was released on November 24, 2018. The 
movie also starring several actress and actors like Jason Momoa, Amber Heard, Nicole Kidman, Willem Daffoe, Patrick Wilson, Dolph Lundgren and Yahya AbdulMateen II.

In this study, the researcher focuses on uterances in term of character educational values that spoken by characters. There are 15 types of character educational values spoken by the characters which the researcher found by in "Aquaman" movie directed by James Wan:

1) Respect is a positive feeling or action that is shown to someone or something that is considered important or is held in high esteem. It conveys admiration for a good or valuable thing. Respect can show with an action or spoken way (Suryati, 2018). The example, Arthur loves his father so much. When a tsunami comes, Arthur was separated from his father and Mera helped him. Finally, they found his father. But Tom was not breathing. Mera helped Tom with her superpower. Then, Tom awake and Arthur was very grateful to Mera.

2) Loyalty is an action to shows the support and participation of someone or something expected. Loyalty to someone can be interpreted by an act of helping people who need help. It can be shown as a representation of friendship. The example is King Orm had planned to be an ocean master, then attack the surface world. He did it because he thought the surface people had polluted the sea. Before the ocean was damaged, he planned to stop it. Mera asked Arthur to help her prevent King Orm's planing. Arthur finally agrees to help her.

3) Patriotism value is an attitude that is brave, underlying, and willing to bleed for the nation and state. In other words, patriotism had meant the attitude of one who is willing to sacrifice everything for the success and prosperity of the hometown. The spirit of love and protect the nation (Rahayu, 2012). For the example is asked when King Orm asked why Arthur came to the Atlantis after all this time, and Arthur said he wanted to stop him starting the war.

4) Curiosity value is the desire to investigate and seek understanding of the secrets of nature. A sense of curiosity usually motivates us to seek and know a new thing. So it will increase knowledge and experience in learning activities. It is attitude and action that always strives to find out more deeply and extends from what it learns to see and hear. For the example is when Arthur goes to the Atlantis with Mera. He was very excited and amazed with Atlantis. It made him gave many questions to Mera along the way.

5) Hardworking is inclined to do anything and try hard to be able to achieve the target of dreams or goals. Hardworking can be interpreted as an activity that is done in earnest without training. Hardworking will never stop before the target work is achieved and always prioritizes or pays attention to the 
results that have been done. For the example is Vulko asks Arthur to master everything that Vulko had to teach if he wants to meet his mother. Arthur works hard to passed all tests because he missed his mother so much.

6) Love \& affection value. Generally, love is a positive emotion or feeling kindness, compassion, and affection. It Contained in human beings aimed at other humans or other objects around them. While, affective is a feeling inside the heart that is sincere to love, and give happiness to others, or anyone loves. Affection is expressed not only to the couple but also to love to God, parents, siblings, family, friends, and the other creatures that live on this earth. The example is Arthur and King Orm prepared for Ring Fire. While waiting, King Orm told legend of Karathen. Then, Arthur says that sometimes he wants to know King Orm as his little brother and tells that he was not alone.

7) Responsibility is the sense to assume or give duty and bear the consequences. A sense of responsibility rises because humans are aware of the good and bad consequences of their actions. Besides that, sometimes humans realize they will need to sacrifice. The example is King Orm gave Arthur a chance to leave Atlantis because he could not defeat him. King Orm asked Arthur not to prevent him to attack the surface. He refused it and keep challenge King Orm.

8) Creativity value also known as ability to think and act using knowledge, experience, understanding, common sense and insight. In the other words, wisdom can be interprated as activity based on experimental self knowledge and self transcandence (Suryati, 2018). The example is Arthur communicates with the whale to get in the whale's mouth imitate Pinnochio.

9) National spirit value. National spirit is creating and maintaining the sovereignty of a country by realizing a concept of shares identity of human organizations that have the same goals or ideals in realizing national interests. National spirit is also a sense of wanting to defend the country both internally and externally. The example is Mera knows about King Orm's declare to attack surface world and she does not let it happend. Mera looking for Arthur to help her stop it.

10) Environmental care is a reaction to the surroundings. Not damage the natural environment. Attitude environmental care will create a clean and beautiful environment. Education is the most appropriate tool in providing knowledge, skills, and attitude of environmental care to humans. The example is on the way look for Deserter Kingdom in Sahara desert, Mera complained to Arthur about surface people that waste trash not in the right place. Mera said they are not protect the world and destroy the environment.

11) Peacemaker is the attitudes, words, and actions that cause other people to feel happy and secure in their presence. Where, attitudes, words and 
actions are integrated into one (Kemendikbud, 2013). The example is Arthur and King Orm fought on land. Then, Arthur defeats him. King Orm was disappointed and asked Arthur to kill him. Atlanna cames then interrupts the two of them and says if she loves them both.

12) Honestly is tell the truth, not to lie or say things that happen/fact. Honestly can be interpreted as not cheating. Doing something by applicable rules and so forth. It also can mean a similar act between one's intention, words, and deeds. The example is King Orm judge him betray the throne and defend Arthur all this time. Vulko not deny King Orm and explain that Arthur twice better than King Orm to be a king of Atlantis. King Orm was very angry and imprison him.

13) Friendly is a natural behavior of people who are easy to get along with. An example of a friendly attitude is good talker, smiling with others, polite, easy to helping others, greeting, and helping selflessly. This is signs with sincerity, and prejudice of all people (Kemendikbud, 2013). The example is Tom saved Atlanna from a sea storm. Then he took care of Atlanna at his house and treated her kindly.

14) Discipline is in compiles with something that is believed to be a responsibility. Discipline means an effort to make someone have the ability to obey a rule. The example is Atlantis has a rule that whoever can be getting King Atlan's trident, legally becomes a king of Atlantis and King Nereus obeys that rule.

15) Tolerance is the attitude of respect and allows a different opinion or view. In this case, a person must respect the opinions of others who are different from his stands. Generally, humans always have different views or opinions. This differences must be left as long as it is still in the right way (Kemendikbud, 2013). The example is King Orm asks the Fisherman kingdom to join them attack the surface, but King Ricou disagrees and says the Fisherman will study the surface, not to destroy them. Then, King Orm appreciates King Ricou's decision.

\section{CONCLUSION}

From this analysis, the researcher founds fifteen character educational values in Aquaman movie, there are: are honesty, tolerance, dicipline, hardworking, creativity, curiosity, national spirit, patriotism, friendly/communicative, peacemaker, environmental care, responsibility, loaylity, respect, love \& afferction. However, the dominant character education values in the movie is responsible, and peacemaker. 
The character educational values are reflected in the Aquaman movie explained in the utterances and act every character in the movie. Every utterance has been analyzed based on KEMENDIKNAS's formulation.

\section{REFERENCES}

Aquaman (2018). Retrieved on February, 10, 2020, IMDb: http://www.imdb.com/title/tt1477834/plotsummary.

Aquaman (Film). Retrieved January, 8, 2020, from Wiki Aquaman: https//dcextendeduniverse.fandom.com/wiki/Aquaman.

Barsam, Rcihard. Looking at Movies: An Introduction to Film. New York, London: W.W Norton \& Company, 2016.

Bo, Bao. "The Differences Between Novels and Films-Enhance Literature Teaching by Using Films," Education Review, Vol. 7. July, 2008.

Christoper P. Jacobs, Film Theory and Approaches to Criticism, or, What Did That Movie Mean?. Dakota : University of North Dakota, 2013).

Dewi Anggraeni, Pamamita. "The Analysis of Moral Value of the "Dangerous Minds" Movie." Salatiga: STAIN Salatiga. 2012.

Dwi Suryati, Selvi. "An Analysis Of Educational Values In "Life Of Pi" Movie." Lampung: UIN Raden Intan. 2018.

Eder, Jens. Characters in Fictional Worlds: Understanding Imaginary Beings in Literature, Film, and Other. Berlin: Hubert \& Co. 2010.

Farrell, Michael. Foundations of Special Education. Singapore: Wiley Blackwell Publisher, 2009.

Gioia, Dana, and Kennedy X.J. Literature: An Introduction to Fiction, Poetry, and Drama/Includes. New York: Harper Collins Collague Publisher, 1995.

Humaira, Maulidina "An Analysis of Moral Value in'Zootopia' Movie." Aceh: Universitas Darussalam. 2018: 1.

James Mcgee, Sharon. Analyzing Literature: A Guide for Student. Salina: Kansas State University, 2001.

Kothari, C.R. Research Methodology Methods and Techniques 2nd Edition. Jaipur: University of Rajasthan, 2004.

Mukarromah, Siti. "An Analysis of Character Educational Values In" Zootopia" Movie Script" Ponorogo: IAIN Ponorogo, 2019.

Penguatan Pendidikan Karakter Jadi Pintu Masuk Pembenahan Pendidikan Nasional. Retrived April, 17, 2020, Kementerian Pendidikan dan Kebudayaan: https://www.kemdikbud.go.id.

Rahayu, Puji. "Murti Nilai-Nilai Pendidikan Karakter Pada Materi Ajar Buku Kreatif Berbahasa Dan Bersastra Indonesia Untuk SMP Kelas VII Terbitan Ganeca."Surakara: Universitas Muhammadiyah Surakarta, 2012. 
Qoyyimah, Uswatun. "Theories of Moral Education and Implementation in Indonesia: Reenergizing Cultural Identity and Addressing Future Challenges." Education. 6. December, 2015.

R, DiYanni. Literature: Reading Fiction, Poetry, and Drama, Compactedition. Singapore: McGraw- Hill. 2001.

R. Frankle, Jack. How to Teach about Values: An Analytic Approach. New Jersey: Prentice - Hall Englewood Cliffs, 1977.

Riyana, Cepi. "The Development of Three Dimensional Animation Film for Character Education Media in Elementary School." Educational Technology, 2. 2015.

Seshadri, C. "An Approach to Value Orientation of Teachers' Education", Journal of Value Education, 5 (2005), 83-85.

Sinha, Sudhinta. "Teaching 'Human Values' for Building Character and Shaping Personality" Journal of Literature of Humanities, Vol. 5. June, 2017.

W. Creswell, John. Education Research Planning, Conducting, and Evaluating Quantitative and Qualitative Research $4^{\text {th }}$ Edition. Lincoln: University of Nebraska, 2011.

Yusof Sharjeel, Muhammad, "Use of Films for Teaching Social Values in English Classes at Elementary Level." Journal of Elementary Education, 1. 2013. 